\author{
NAGy, TERÉZIA PHD \\ nagy.terezia@gmail.com
}

assistant professor (University of Debrecen, Department of Sociology and Social Policy)

\title{
At the Southeastern End of Schengen
}

\author{
Accepting Refugees in Hungary in 2015's refugees' wave
}

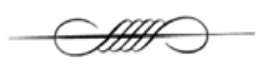

\begin{abstract}
In my study I would like to show how the refugees' situation, motivation and lifestyle have been criminalized in the public discourse (political, press and social public discourse) despite the fact that the Hungarian asylum procedures seem to be converging to the EU standards.

I will approach the acceptance of and behaviour towards refugees in two ways: based on my experience from fieldwork carried out in diasporas in Budapest and based on my analysis of the press from the perspective of the host society. These approaches are important because my results show that socio-cultural acceptance is demonstrated almost exclusively by the diasporas even though the economic and official procedures manifest in the body of the host (Hungarian) society.

I would also like to speak about the picture the Hungarian media and the government's discourse show of people crossing the border illegally, how it raises fear and uncertainty among them. This kind of influence conveys messages which hinder fitting in in various aspects, obstruct integration, and at the same time make transnational communication among refugees stereotypical and equivocal. Consequently, ethnically or religiously homogeneous connections are getting stronger, while the importance of diasporas with weak economic, political and advocacy background is also increasing. However, the newcomers hardly ever enter the Hungarian scene.
\end{abstract}

\section{KEYWORDS}

refugees, criminalization, public discourse, acceptance of refugees, behaviour towards refugees DOI 10.14232/belv.2018.4.4 https://doi.org/10.14232/belv.2018.4.4

Cikkre való hivatkozás / How to cite this article: Nagy, Terézia (2018): At the Southeastern End of Schengen. Accepting Refugees in Hungary in 2015's refugees' wave. Belvedere Meridionale vol. 30. no. 4. 61-82. pp.

ISSN 1419-0222 (print)

ISSN 2064-5929 (online, pdf) 
(Creative Commons) Nevezd meg! - Így add tovább! 4.0 (CC BY-SA 4.0)

(Creative Commons) Attribution-ShareAlike 4.0 International (CC BY-SA 4.0)

www.belvedere-meridionale.hu

\section{INTRODUCTION}

The reception of refugees is a complex issue which includes a formal procedure, the host society's attitude. This includes both the political approach, which is able to affect the formal procedure, and the legislative environment that asylum seekers encounter. The attitude of the host society is also fragmented: while most citizens are not involved in these matters, small groups have committed themselves to helping refugees, and civil society initiatives emerge and are supported by the diasporas as much as possible. Other groups, however, reject the reception and presence of refugees, emphasizing nationalist values verbally and occasionally physically against the refugees.

In this study I would like to present this complexity: the participants, their actions and the media appearances of related discourses. 2014-15 brought significant changes to the legal environment regarding the reception of refugees, their media appearances, social perception, which present the changes well, especially the responses to the challenges and the extremes.

It is an important approach for me that the changes in the reception of refugees can be understood as encounters: meetings between civilians and refugees, refugees and the law, diasporas, refugees and the host society, politicians and the challenges.

In this study I would like to interpret this diverse, complex and dynamic process by (1) presenting the firm political discourses and the responses thereto starting from the turn of the years 2014-2015, including the solidarity initiatives to border hunter volunteers and vigilante patrols. I present in detail (2) the networking initiatives in the civil society and (3) the robust statistical data of reception and the changes in the reception conditions. Finally, (4) I will close this paper with a case study of negative reception. This case study shows that the refugees, even if they stay in Hungary, bind strongly to their diasporas through their networks and homogeneous links, but are hardly connected to the host society.

\section{The RECEPTION OF REFUgeEs IN Hungary - A THEORETICAL APPROACH}

I interpret the reception of refugees as a diverse field of transnational encounters, fears, foreignness and xenophobia, in order to simultaneously interpret the constantly growing anti-refugee attitude, and the physical, media and public discourse appearance of refugees. I would also like to present how the reception of refugees leads to a network that strives for homogeneity and has both positive and negative experience. This network is created in the new environment, under the conditions of the host society. I call this process neo-integration because of these properties, considering the special condition, according to which this network knows no borders, but is very much aware of the dichotomy of $u s$ and them. 
I interpret transnational relationships as an opportunity which allows refugees moving forward (and sometimes backward) to internalize cultural knowledge and reflect on their own and on other people's cultural properties, and allows cultural and social capital to be converted into economic capital, and vice versa. On the other hand however, reception is associated with concepts of indifference, detachment and xenophobia. Only a fraction of the Hungarian society has become inclusive, but in their case multicultural experience accumulates and internalizes and the image of remote regions (countries of origin) appears.

My theoretical approach is based on several years of fieldwork carried out in diasporas and among refugees in Hungary from East and West Africa, the Maghreb and South Asia and later among waves of refugees in 2015 where I utilized my previous experiences as a researcher, volunteer and mediator. Meanwhile my focus ranged from the viewpoints of refugees and diasporas, and the way they were pictured by the host society and the media. This pluralistic approach has led me to study the reception of refugees not just from the viewpoints of neo-integration, hybridity and transnational encounters, but also from the perspective of social and political discourses, reception and rejection. At the same time, I return to the considerations of foreignness, which include the discursive analysis of stereotypes and the interpretation of the presence of authority and power.

Studies often describe the dynamic movements and variability which characterize transnational spaces in a static way, and analyse socio-economic phenomena in a given locality. While dealing with a local phenomenon - the reception of refugees in Hungary - in this study I intend to reflect on this as a much more global phenomenon from the perspectives of the refugees, the host society and the power alike, based on experience, political discourses and information (and misinformation) circulating in the networks.

Diasporas come into being as separate entities within the host society's body and reflecting upon that (Nagy 2009 and 2011), and create a distinct milieu through preferential choices, in which the mythical Home (Safran 1991) and the endeavour to homogeneity are in the focus. However, the diasporas are also networks consisting of structured groups which strive for ethnic and religious homogeneity within the network, but on the periphery they have comparative and reflexive links to other diasporas and the host society, and this leaves space for transnational and intercultural approaches (cf. Wilson 2009, Clifford 2007, Hannerz 1997, Tilly 2001, Faist 2010). However, members of the diasporas are bound to global diaspora networks through their relations, which further strengthen their exclusion from the host society.

The presence of refugees means cross-cultural relationships and challenges. This partly manifests in mutual stereotypes found in narratives, and partly in the fear of foreigners (cf. Glick Schiller 2010). The exigency of adaptation (see A. GERGELY 2005), which compels refugees to enter the path of integration, does not force the host society to do so. However, the evolving neo-integration, which is a new concept of integration, is based on distinctions, failures at several things (e.g. relations) and the convertibility of diasporic relations. Neo-integration moves towards the diaspora along the relational successes and failures, thus forming a unique island where the dynamic effect of foreignness and exoticism can be detected.

The dynamics of transnational encounters can be observed on the edge of the diaspora (see WAHLBECK 2002). The static, permanent link between two or more ethnic groups has been 
replaced by a reflected, contextual relationship. It is heterogeneous ethnically and religiously (and in other aspects) and is only sustainable in the diaspora in case of mutual satisfaction. Transnational relations preserve and nurture the original cultures and convey new elements (CLIFFORD 1992). The motivation of transnational relations is not only a sort of cosmopolitanism, but a necessity, and in the case of refugees it is particularly important to interpret the transnational connections and evaluate them with network analysis methods so that we can grasp the impact of transnational relations on the neo-integration strategies of refugees (NAGY 2010, 2011).

The diasporas in Hungary are surrounded by a 'traditionally xenophobic' society with an aversion not only towards people from faraway countries, but also towards other social groups (see SIK 2012, RAJARAM - ARENDAS 2013. 203.). This is in part caused by authoritarianism appearing in identity (FÁBIAN - SIK 1996). However, it is equally important to perceive exoticism and understand the nature of foreignness and xenophobic narratives. Based on this consideration, the analysis of the inherent power concepts of discourses (SCHIFFAUER 2004. 159-160.) and the fine analysis of foreignness can be the way to understanding the attitude towards refugees. In this manner the transnational and diaspora-focused neo-integration and the anti-immigrant attitude based on negative stereotypes can be observed concurrently.

The history of the Hungarian asylum system shows low acceptance rates in addition to large-scale onward migration. Onward migration can primarily be observed among refugees, subsidiary protection beneficiaries and asylum seekers who are expected to be able to integrate more successfully based on the socio-demographic indicators (see KovÁTs 2003). It is also known that the more successful networkers can operate the global network of diasporas to create the opportunity to resettle and join the world of multigenerational diasporas (Brubaker 2005), while in the imaginary space of nation-states one may observe the proliferation of reflexive, transnational, but homogeneity-aspiring diasporas. In the social, political and power discourses departures, success, talent, humanity as well as arrivals, failures, the social burden and the nation's survival are actualized. Sensitive approaches are marginalized, and the discourses are no longer determined by hybridity, fluidity or multiculturalism, but rather by identity, the borders, inclusion and exclusion, political, legal and labour market aspects as well as cultural and religious challenges of being in the same space.

Aversion, the fear of the unknown, the lack of information about the unknown surrounding the increasing number of refugees as well as migrants and people with migrant background have led to a heightened discursive strategy (BERNÁtH - MEssing 2015). This strategy has given way to the special framing of issues related to refugees, so while we examine inclusion we can also get to know non-reception discourses. Consequently, authority, sovereignty, power discourses and criminalization provide the background in which we can interpret the aspects of the refugees' reception, settlement and onward migration. However, in 2015, particularly during the summer of refugees, discourses emerged along the line of sensation, shock and self-justification (see FOKASZ 2006, 2008) in which left- and right-wing media outlets and forums, disaster tourism and enthusiastic volunteers also played a major role.

The reception of refugees can be interpreted in a dichotomous field, in which the host society and newcomers, locals and aliens, regular and irregular, the worthy and the fraudulent clash 
with each other, while the cause of voluntary and forced migration is restricted to the experts' discourses (cf. Holmes - CASTANEDA 2016. 16.). In addition, this dichotomy is a two-way process where the interests of macro-politics and the economy collide with the grassroots initiatives of the civil society, and the refugees and asylum seekers who arrived in large numbers in the migration wave get stuck in between. The powerful appearance of interests and commitments provides a framework for the concept of crisis (which is already assigned with values), and the search for sensation in the media is also present. For this reason, in this study I have decided to interpret the reception of refugees, the forces influencing reception and the partial results of the dynamic process (i.e. changes in legislation and its implementation, powerful manifestations or withdrawal to homogeneous zones) from several directions.

\section{RESEARCH METHODOLOGY}

The results in this study are based on fieldworks carried out among refugees living in Hungary between 2005 and 2014 (when I examined the refugees' neo-integration, networks and the operation of diasporas) and in 2015 (when I focused on the reception of refugees arriving through the Hungarian-Serbian border and related narratives). These were completed with the analysis of narratives of non-governmental organizations and civilians as well as with a wide-perspective discourse analysis. During the discourse analysis I examined the media appearances of 2015, more concretely a differentiated text corpus compiled from articles that appeared in left- and right-wing media outlets related to refugees and migrants. When I use the term media in this study, it is based on the discourse analysis of a total of 7,500 articles that appeared in left-wing media, 5,900 pieces from right-wing media and 685 pieces from local (Szeged-based) papers. The articles were downloaded from the selected media websites and grouped accordingly, and the dates of publication were also indicated. I analysed the text corpus partly via a concordance study to know what other terms accompany the ones related to migrant discourse in the particular media. This meant relevant terms appearing up to 45 characters away from the term refugee or migrant in both directions. I also made efforts to follow the change of terms. I examined the concordance of terms with the linguistic software WordSmith. The results show the frequency of terms and their concordance. These data were processed and visualized with the network analysis software Gephi. The terms are the network nodes, the size of the nodes indicates the frequencies, while the relations of the concepts are shown by the edges. However, the impressive presentation of the results in a network requires an interpretative approach, therefore I carried out the qualitative examination and narrative analysis of the narrative blocks organized around concording words.

The results of the fieldwork and the discourse and narrative analysis are interpreted side by side in this paper, while I seek to ensure that the chronology of the events can be tracked, such as the changes in legislation or the decisions of the government which changed the discourse and institutional framework of the reception of refugees. 


\section{PubliC DisCourses, COUNTER-REACTIONS, SOlidARITY AND THE CRIMINALIZATION The concepts of 'migration' and 'refugee' in the political and media discourse and in research}

Hungarian discourse on migration took a sharp twist in the spring of 2015; the previously silent negative attitude in political statements and the government's media campaigns turned into open rejection. While at the turn of 2005-2006 the total number of media appearances of refugees - in two outlets - remained under 150, during the migration wave thousands of articles and writings were published (cf. VICSEK et al., 2008). However, this meant not only quantitative growth but also a diversified, sensation-focused approach, divided in accordance with political orientation: This also indicates that the public, political and social discourse turned towards the issue of refugees and asylum policy. This move gave an opportunity to interpret the reception of refugees by discourse analysis methods.

In May 2015 Hungarian Prime Minister Viktor Orbán said: 'We want no more people to come. Those who are here should go home.' (MNO, 08/05/2015) We can interpret it as a programmedefining sentence. By then it was known that a so-called national consultation would start on migration and the government underpinned its consultation with a billboard campaign a few weeks later. The wave of refugees during the spring urged right-wing politicians and the media to use powerful statements such as 'subsistence immigrant'. Then both sides of the media softened their language to 'refugees' and 'migrants' used simultaneously. With the unfolding media campaign and the growing wave of refugees, the terms 'illegal migrants', 'illegal border-crossers' and later 'illegal invaders' appeared in the public discourse. Furthermore, the right-wing media and social websites increasingly began to refer to migrants as criminals and continent conquerors, and made racist and islamophobic comments on them. Meanwhile, the left-wing media tried to reduce fear and kept referring to those arriving in the country as refugees or migrants. It is interesting that Hungarian papers in the Serbian province of Vojvodina referred to refugees as 'temporary guests'.

However, the discourse analysis of the media clearly shows that researchers and professionals struggle to have the concepts of asylum seeker, refugee, subsidiary protection beneficiary and migrant interpreted as they should, while the term migrant was assigned negative connotations. It is obvious that the political discourse is purposely built upon the fact that Hungarians are not familiar with the traits of being a refugee and an array of anti-refugee measures can be justified by drawing fear. Within a few months we got from the term 'refugee' to 'illegal border-crosser', acts were adopted to allow building the fence and make asylum seeking inaccessible to the majority. Meanwhile, the social gaps were deepening and the right-wing social media focused on being against the refugees and their helpers, referring to them as 'migrant-huggers', while left-wing sites can be described as supportive of refugees, they criticise the government and present the human side of the crisis.

Public discourses have started to focus on refugee camps, near which people feel insecure and claim that crime rates have increased, although this has not been confirmed by the statistics. Plans for constructing new camps have been received with fear and rejection, especially in Debrecen, where residents are trying to get rid of the camp. However, the camp will be closed only in December. In the meantime, new terms like transit zones, transits, immigration detention centres and the Hangar (the storage building temporarily used as a guarded reception centre) and unaccompanied children 
appeared, then the concepts and pictures of razor wire fence, border closure and collection points emerged. However, the interpretations depend on the political orientation of the media. One side discusses the waves of refugees from the perspective of security, terrorism and healthcare (e.g. Ebola and other epidemics), while the other side deals with the aspects of the humanitarian crisis. The Schengen borders, the Dublin Regulation, the fate of refugees: they have suddenly become daily topics in newspapers and the situation has intensified thanks to active readers on both sides. Consequently, cases which earlier hardly got any media attention, and characterized the status of refugees who had arrived earlier, are now given more publicity: legal procedures conducted without interpreters, poor quality and religiously unacceptable meals, or corrupt practices and humiliating treatment in immigration detention centres.

Naturally, in this study I also address the concepts of discourses responding to the refugee situation and legislative and scientific terms, so I distinguish the concepts of migrants, refugees and asylum seekers. At the same time I must also make a distinction between refugees who had arrived before the wave of migration started and the ones who arrived (and left) in mass numbers in the summer of 2015.

\section{Criminalization processes in the media - results of the discourse analysis}

The previous silence of the government regarding the asylum system was replaced by intense anti-refugee communication in 2015. It emphasized the significant growth in the number of asylumseekers, disregarding that most applications are closed before any in-merit decision is reached since the applicants leave the country after submitting the applications. Consequently, statistics of expenditures related to asylum seekers and refugees are debatable. However, this was enough for the government to launch a so called national consultation in which tendentious questions blended the issues of migration and terrorism. Besides, some of these questions were quite difficult to answer with a clear conscience, e.g. deciding between supporting Hungarian families or refugees (National Consultation 2015). In addition, the government threatened the population with the number of refugees coming and returned to Hungary based on the Dublin procedure, and by calling them economic immigrants. Initiatives were set off against this campaign almost immediately, so the government supported its national consultation by a billboard campaign, triggering a countercampaign from the civilians' side. While the government is anxious about the national culture and Hungarian jobs, and addresses refugees in Hungarian, the counter-campaign billboards apologize in English and reflect to current political issues and multiculturalism in Hungarian (e.g. by citing the first Hungarian king, Stephen I: "Weak and fragile is a kingdom with one language and custom").

An especially important element in the government's communication is the restriction of immigration after the terrorist attacks in Europe and that it emphasizes its own courage and openness. We must not ignore that this happens in a milieu which rarely encounters refugees, has a limited knowledge of foreigners but xenophobia is still around 39-46\% (TÁRKI 2015). As much as $64-67 \%$ of the population thinks that refugees pose a threat to Hungary and should not be let in according to a survey conducted by Republikon Institute (MTA 2015). Therefore, 
it is important that the fundraiser prankster party (MKKP - Hungarian Two-Tailed Dog Party) and its non-governmental partner (Vastagbör - Thick Skin) collected far more donations for the counter-campaign in a few days than expected (see The Guardian, 06/01/2016), and the politically inactive civilians actively participated in writing lines for the billboards against the anti-refugee campaign. The government's anti-refugee activity continued: relying on an inaccurate analysis of the national consultation they repeated the billboard campaign twice: both in transit countries and in the domestic, Hungarian language campaign based on the results. Meanwhile, leftwingers and refugee-supporting civilians saw a hate campaign, and new, 'not in my name' types of narratives were born.

Media framing is divergent: left- and right-wing media contextualization is different, they highlight different elements, while the increasing anti-refugee attitude in the public political discourse also thematises discourses on refugees. In this context, terms related to refugees are changing, narratives related to terrorism and crime appear in addition to rigorous and negative statements that are so strong that they are constantly dealt with even by the left-wing media. An especially important narrative block reports on illegal border crossings, border closure, illegitimate ways of arrival ending up by criminalizing border crossing, and by showing the picture of an infiltrated Muslim terrorist (see HoLMES - CASTANEDA 2016. 18) and in general a crisis with never-ending risks.

Compared to its political commitments, the media thematises the public discourse on refugees well, and if there are any common points, such as the concepts of help or multiculturalism, they appear in different contexts. In the following figure I intend to present the results of articles that appeared in left- and right-wing papers on refugees in August and September 2015.

I have examined the relevant terms that appeared in conjunction with the concept of refugees from the aspects of concordance and frequency. Figure 1 clearly shows that the concepts relating to the status of refugees, their origin, the challenges (security, health, legal, housing, transport challenges) can be found together in both the left and right-wing media, but both sides have developed their own conceptual frameworks, which reflect their approaches well. While left-wing media outlets highlight the humanitarian issues, the right-wing media focuses on the legal, criminal and territorial aspects.

A concordance study establishes the narrative interpretation of media framing in terms of quantity and context alike. The framing in government-related media has also been intentional: sometimes data, presentation and contextualization make media consumers move away from the empathic understanding of the refugees' situation. They speak about migrants without introducing them, or show unattractive migrants, migrants without children, and sometimes show refugees who litter, disregard the rules or let their children scribble on the pavement. The fear from Ebola has been taken over by anti-terrorism supported by occasional unruly conduct and European examples. At the same time, the left-wing media tried to uncover the causes of the refugee wave as well as the migrants' fate and experiences during the journey.

This situation is heavily complicated by the fact that the media (and the majority of civil organizations) are forbidden to enter reception and detention centres, so information on how migrants are taken care of in Hungary can be gathered along the way in transits maintained by civilians. In addition, the left-wing media also highlighted how former Hungarian refugees and migrants 
were received in the West, and the effects of xenophobic, anti-refugee, racist and islamophobic discourse also appear on both sides - albeit in different ways - ranging from the lard attack on a mosque to physical abuse on citizens with migrant background and many minor cases which have accompanied the wave of refugees. Near the Schengen border the media noticed the concerns and fears of the populations of small villages and farms early on, but the local people also became bolder and reported much greater damage than assumed, and occasionally the locals' reaction grew hysterical. The fears of the local population are well thematised by the many distorted stories, hatred-inciting and unfair comments appearing in the social media, forums and groups as well as by both sides of the battle of comments. However, it must be mentioned that scientific measurements of these fears in Szeged, a city near the border, show a different picture than journalistic sources: residents demonstrate a slightly more positive attitude than the national average: $43 \%$ of them would receive refugees persecuted in their home countries, and while 53\% are intolerant according to national surveys, this ratio stands only at $26 \%$ in Szeged (Szeged Studies, 2016).

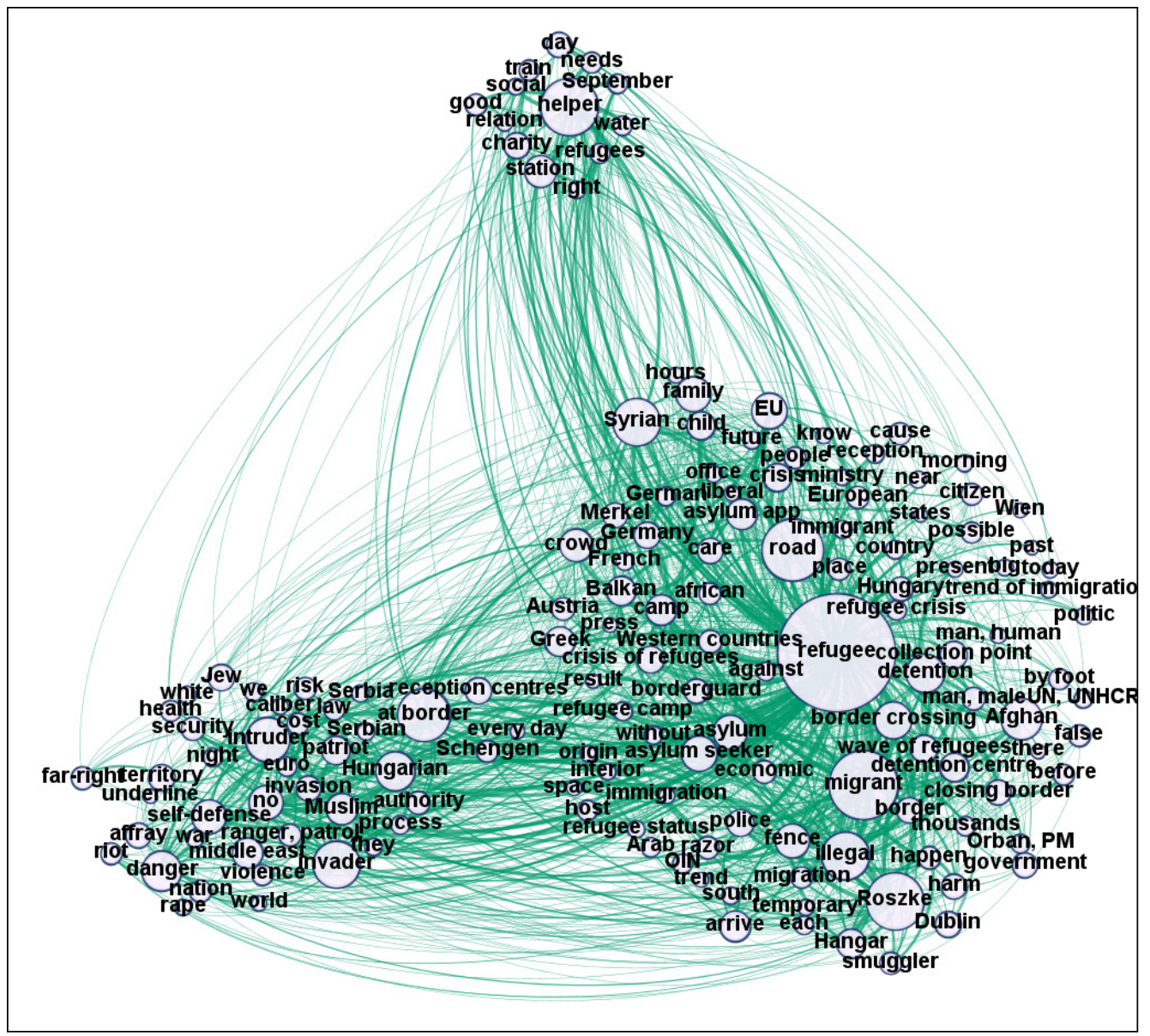

FIGURE 1 About refugees August-September 2015. Concordance analysis and visualization of relevant articles that appeared in Hungarian newspapers 
Pro-government media outlets have exploited the opportunity to strengthen their support base by actions against the refugees, and by mixing the term 'refugees' with 'economic immigrants', 'social benefit abusers' or 'extremists'. However, the attack provoked strong moral resistance, which encouraged many people to volunteer. Solidarity induced a moral community and collective actions which could respond to the needs, the social and political challenges in a higher volume (see CАвОт 2016. 152-153.).

\section{From right-wing discourse to border hunter 'volunteers'}

While we could only see a continuously growing, permanent wave of migrants, the right-wing media already reported on the border pressure, stories that conveyed the fears of the local people, as well as on field rangers and civil guards on the Hungarian side of the Serbian-Hungarian border, who consider it a duty to capture refugees crossing the green border, and are strengthened by local decision-makers in this activity. When the migration pressure began to intensify in the spring of 2015, mounted field rangers, civil guards and border hunter volunteers appeared, and later at the peak of the refugee wave, border protection units were deployed saying that the homeland had to be protected, with arms if necessary. A whole range of anti-refugee movements were launched starting from border hunters, border security brigades, "outlaws" (betyárs) and voluntary border protectors. Their discourses showed wide-scale xenophobia. In addition, a strong narrative appeared on territoriality which depicted the Hungarian Schengen border as the defender of Europe, European culture and of the Christian Europe. Such discourses legitimized the practice of using night vision binoculars to detect and seize refugees and keep them back until the arrival of civil guards or the police. Some groups are built up like an authoritarian system, similar to the structure of the military, and try to copy the organization and functions of the army. In other groups antiEuropeanism appears in conjunction with nationalism. However, most groups do not turn their words used in social media comments into actions.

\section{CIVILIANS IN ACTION - RESULTS OF THE FIELDWORK AMONG CIVILIANS Solidarity and grassroots organizations}

After Hungary's transition to democracy in 1989, smaller, isolated associations were set up to bring the diasporas together. After that, professional organizations for migrants, multicultural knowledge and sensitivity were founded which have been actively involved in the work of the reception centres and advocacy, and have continued supporting the integration of refugees after they leave the centres. About one and a half years before the refugee wave of 2015, the MigSzol migrant solidarity group was set up, which was one of the organizers of independent civil initiatives during the refugee wave.

At the beginning of the wave, civilians faced the fact that the Immigration Office (OIN) dismissed refugees without information, food and accommodation and sent them to railway stations to find their ways to the designated reception centres. Soon new groups were organized via Facebook which tried to provide first-aid-like support at the local railway stations. Within a short period of time these teams were helped through a coordinated flow of information, so they knew exactly what type of support the groups of refugees arriving by train needed. 
Professional task sharing (fundraising, storage, translation, interpretation and sandwich-making) quickly organized the helpers into a network working beyond its capacities. The number of civilian helpers multiplied within a few days, partly in response to the government's anti-refugee campaign and because of the need for assistance, though at the same time the number of refugees entering the country reached 1,000-1,500 per day. Meanwhile, the oldest, most experienced organization that had worked with refugees for years had to leave the Hangar for the lack of resources. Places controlled by the police and the border guards (OIN, HRK, Hangar) were temporarily left without civilian helpers.

After several months of "service", the closure of the Serbian-Hungarian border and later that of the Croatian-Hungarian border almost shocked the helpers. Internal conflicts came to the surface and the gap between the organizations continued to grow. Many people returned to their daily lives while others looked for opportunities outside the borders to help refugees or tried to use their experience at helping others and fundraising to the benefit of Hungarian disadvantaged people. Overall, the masses of helpers (thousands of people) gathered positive experience, their social networks widened and they gained multicultural experience both from fellow helpers and refugees. However, the respect of large, conventional organizations declined because they moved much slower and had fewer tools and helpers than the newly created, energetic groups, even though cooperation of the latter ones was also characterized by competition. During the days of the Hungarian-Serbian border closure (which is considered as a turning point) many Hungarian and foreign organizations, self-organizing groups, churches and friends flocked (cf. ROZAKOU 2016. 185. on pro bono transfers) to the major locations, which resulted in a festivallike atmosphere, chaotic moments, competition, success and resentment at the same time. The chaos was caused not only by amateurism and disorganization, but also by the fact that each group had a definite idea of how help could and should be rendered. However, this chaos led to new pro-refugee cooperation projects that spanned the weeks following the chaos. These collaborations still provide a supportive and receptive environment for new refugees and help everyday life in the reception centres.

\section{RECEPTION PROCESSES OR HOW NOT TO ACCEPT REFUGEES Asylum seekers and the refugee processes - fieldwork experience}

The rules on refugees and the asylum procedure have considerably changed in recent years and while the changes seemingly served harmonization with EU legislature (see RAJARAM - ARENDAS 2013), in reality enforcement happened in a lean way, and those who wished to stay in Hungary were left with a small chance to integrate. A good example is that most applicants are no longer put in detention centres due to European pressure. However, since 2013 one tenth of asylum applicants have been placed in closed asylum reception centres (source: helsinki.hu). Thus legal aid and civil society organizations have a major role in fostering the integration of the few people that applied for asylum or who wished to stay in Hungary after the decision. In the regular procedure the Office of Immigration and Nationality conducted a shorter and a longer interview to decide whether the applicant would be granted refugee, subsidiary protection beneficiary, or accepted status, or would be rejected. During this time, the applicant should stay in an open refugee camp 
or in a closed asylum reception centre. The applicant may appeal a rejection and request a judicial procedure. According to statistics, the majority of the applicants $(90 \%)$ left the country before or even after the decision was reached. Obviously this was due to the lack of housing and social support as well as the school integration of children.

The growth in the number of refugees in 2015 was accompanied not only by an anti-refugee campaign, but also by the change in the asylum system, on the basis of which international protection seems inaccessible in Hungary. Since August 2015 Serbia has been considered a safe third country, and new migrants coming from there are turned back, their asylum applications are deemed unacceptable, and if Serbia does not accept them, they are detained. An accelerated procedure has also been introduced. This procedure is conducted in the absence of personal documents or if it cannot be determined where the applicant comes from, whether he/she has the right to apply for asylum, or whether he/she has arrived via a safe third country (more can be found about its importance in RAJARAM - ARENDAS 2013. 204.). The appeal has no suspensory effect, so the applicant may be deported for the time of decision. The personal interview is no longer mandatory for the court and the provision of native language interpreters has become even more uncertain (see Hungarian Helsinki Committee, 10/07/2015).

The news of Hungarian legislative changes were considered by many to have an accelerating effect on the movement of refugees via the Balkan route, as they wanted to get into the EU before the changes took effect. After the migrants' arrival and registration in Hungary, the OIN assigned them a refugee camp, and gave a 48-hour travel card with which they could reach the camp from the railway station. However, the travel cards were only valid for journeys towards the refugee camps, and as weeks went by, the refugees found it more and more difficult to travel within the country. They could not travel to the western borders. Later separate carriages were assigned to them, and they could only get off at junctions leading to refugee camps (sometimes the doors on the carriages were locked from the outside). Many refugees had valid tickets to travel to the west. They were allowed to buy the tickets, but were not allowed to travel. Refugee camps and transit zones at train stations set up by civilians were full by the end of the summer and the growing crowd wanted to leave for the West. Refugees who were reluctant to register and be fingerprinted at collection points at the Southern border in Röszke and Ásotthalom as well as in the Hangar rebelled several times against being kept in Hungary forcefully. Meanwhile, some trains carrying refugees could leave the capital towards the western border, others could not. This unpredictability and the fact that a train carrying refugees was 'diverted' by the police (the train left for the west, but it was stopped at the nearest refugee camp), and the fact that later these trains were altogether cancelled, showed the uncertainty of the Hungarian authorities and further undermined confidence in them. Finally, the 'March of Hope' began and hundreds of refugees started walking westwards, while civilians gave them water, food and first aid along the route. While the debate was going on whether or not the transportation of refugees should be allowed on the Hungarian side, Austria organized convoys and took the refugees to the Austrian-Hungarian border, which they crossed on foot, and were then helped by Austrian civilians and NGOs.

It is certain that the news about the changes reached the people in the South Balkan in about three days. Greek and Serbian civilians' reports suggested that many of the refugees could hardly believe the news. However, the growth in the number of migrants was also influenced 
by the fact that the images broadcasted by the media about the terrible and inhumane conditions had shocked the western media and politicians, leading to the German Chancellor Angela Merkel giving all Syrian refugees fleeing the war zone a green light to come to Germany. In addition, the new migrant detention centre opened and the Hangar was left empty for a day or two. However, it was needed once again, since the possibility of travelling west and the date of border closure drawing near accelerated the movement of refugees. The responsibility of the German government appeared in the political discourse: the promise of accepting Syrians accelerated the flow of refugees. Meanwhile, Hungarian Prime Minister Viktor Orbán declared that he was glad to welcome kebab house owners because they are organized people, but the ones who had reached Turkish refugee camps were no longer fleeing for their lives. In addition he mentioned the challenge of Roma integration (index.hu, 07/09/2015).

The night before the border closure it had repeatedly spread among civilians, journalists and police officers that the border might be closed in the evening or during the night of the 14th of September, or in the following morning. Meanwhile, hundreds of refugees arrived on the railway track because there were no fences there. The military and the police surrounded the border, armoured vehicles, dogs and border guards turned up, giving a special atmosphere to the night march. The groups of 100 on average were led to the collection point, where Hungarian and foreign volunteers helped refugees in a unique chaos: everybody helped as they could, neither the positions of helpers, nor the allocation of donations were organized. There was neither water, nor lighting, with the latter meaning that a huge amount of donations went to waste because refugees who were transported from the site could not take them. Finally, on 15 September the border was closed with a reinforced freight carriage (creatively called Mad Max Wagon by civilians).

When the Hungarian border was closed, a crisis caused by mass immigration was announced and transit zones were set up in no man's land according to immigration laws. The modified Asylum Act combined with the physical border closure ensured that Hungary would escape the refugee challenges - at least at the Hungarian-Serbian border - as after 15 September, the HungarianCroatian border became the route for refugees for about a month. During this month the asylum system was ambivalent: those who came through the Hungarian-Serbian border faced expulsion and were charged with the crime of illegal border crossing, but those arriving through the HungarianCroatian border were transported by the state in trains, mostly without registration.

After the closure of the Hungarian-Serbian border the crowd swelled at the Röszke border crossing point within hours, law enforcement and military forces as well as civilians on both sides waited for the events to unfold. The mass of refugees became impatient observers, started dismantling the fence and shouting over it to the Hungarian side. Minor incidents also took place as the crowd tried to open the gate obstructing the border-crossing point. Law enforcement officers lined up on the Hungarian side and when the gate was brought down, they pushed the refugees back to the Serbian side. Tear gas and a water cannon were deployed, while some 'leaders' were arrested. According to the government and the police, terrorists were captured, i.e. refugees who had become terrorists by attacking the Hungarian border. The interpretation of current events as crisis and terrorism framed media releases, but disappeared from the public discourse quickly and the 'battle of Röszke' is only remembered by a few. Similarly, only few people remember how uncertain information, changing rules and the roles of civilians and the police contributed to the fact that the crowd started to act more firmly. 
Since the border closure in September 2015, asylum applications can be submitted only at the transit zones, where the police and immigration officers are in charge. However, it soon turned out that most of the applicants would face detention and expulsion. The detention centres, transits, closed asylum reception centres, the detention and the conditions of detention and the lack of access to remedy, social and health services have raised many questions that are examined both by the EU and human rights organizations (see e.g. http://helsinkifigyelo.blog.hu/, http://www.unhcr-centraleurope.org).

\section{The trends of asylum applications}

Asylum applications and the ratio of successful claims are good indicators of the impact of the socioeconomic and legal environment that awaits refugees. Asylum applications terminated without a decision show that those who can move on because the chances of integration and success are small in Hungary. Furthermore, the proportion of decisions granting various forms of refugee status is small, which shows that the legal and institutional conditions promote rejection and negative reception.

Despite the fact that Hungary is not a destination country (RAJARAM - ARENDAS 2013. 202), the number of asylum applications rose year after year, and a sudden change occurred in 2015 when the numbers multiplied on transit routes (Figure 2). In 2013 and 2014 17,700 and 42,000 people arrived and applied for asylum, respectively, while in 2015 as many as 411,000 refugees crossed the country, but only 180,000 people sought asylum. Many of them moved westwards after or without registration. While the February wave mainly comprised of Kosovars, later the largest groups consisted of Syrians followed by Afghans, Pakistanis and Iraqis respectively (bmbah.hu, MTA 2015).

The relatively rapid growth in the number of refugees generated different ideas: refugee camps on the outskirts of towns were intended to be closed in part due to safety reasons, and new ones were planned to be opened. At the peak of the wave, the capacity of the four refugee camps was 1,500 people, but since almost that many people arrived each day, the capacity of the temporary camps was increased to accommodate more people. However, neither administration, nor access to health and social assistance improved and capacities turned out to be insufficient at the peak of the wave. After the closure of the Serbian-Hungarian and Croatian-Hungarian borders, 'late-comers' were placed in transits, detention centres and in closed asylum reception centres.

An asylum seeker's claim is terminated if the applicant stays at an unknown place or fails to turn up for the interview or (in rare cases) when the asylum seeker himself requests termination. The data of the OIN (see Figure 3) clearly reveal that more than half of the procedures end with termination, mostly due to the fact that the applicants leave, presumably for the West, in line with their original intention. If we only look at the merit procedures, we can see that the ratio of positive decisions has drastically decreased.

In 2015 , the overwhelming majority of the 400,000 refugees travelled on to the West, only 500 people stayed at Hungarian refugee camps at the end of the year, and due to the legislative changes, only 100,000 people arrived in the last quarter of the year (927 persons after the border closure). Since vandalizing and destroying the border fence is regarded as a crime, slightly more than 1,000 criminal proceedings have been launched, which have mostly ended with detention and 


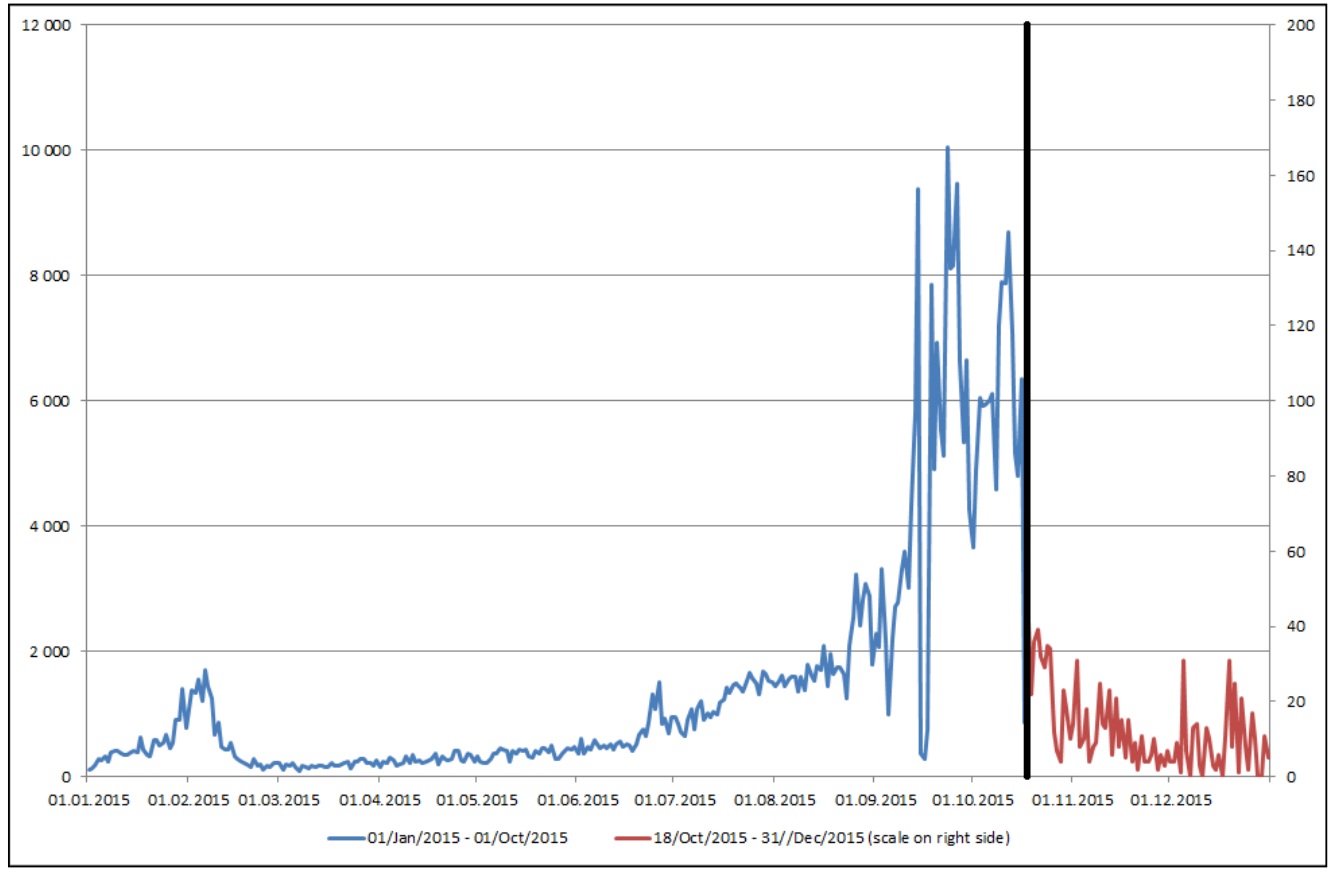

FIGURE 2 Number of refugees, before and after border closure, 2015

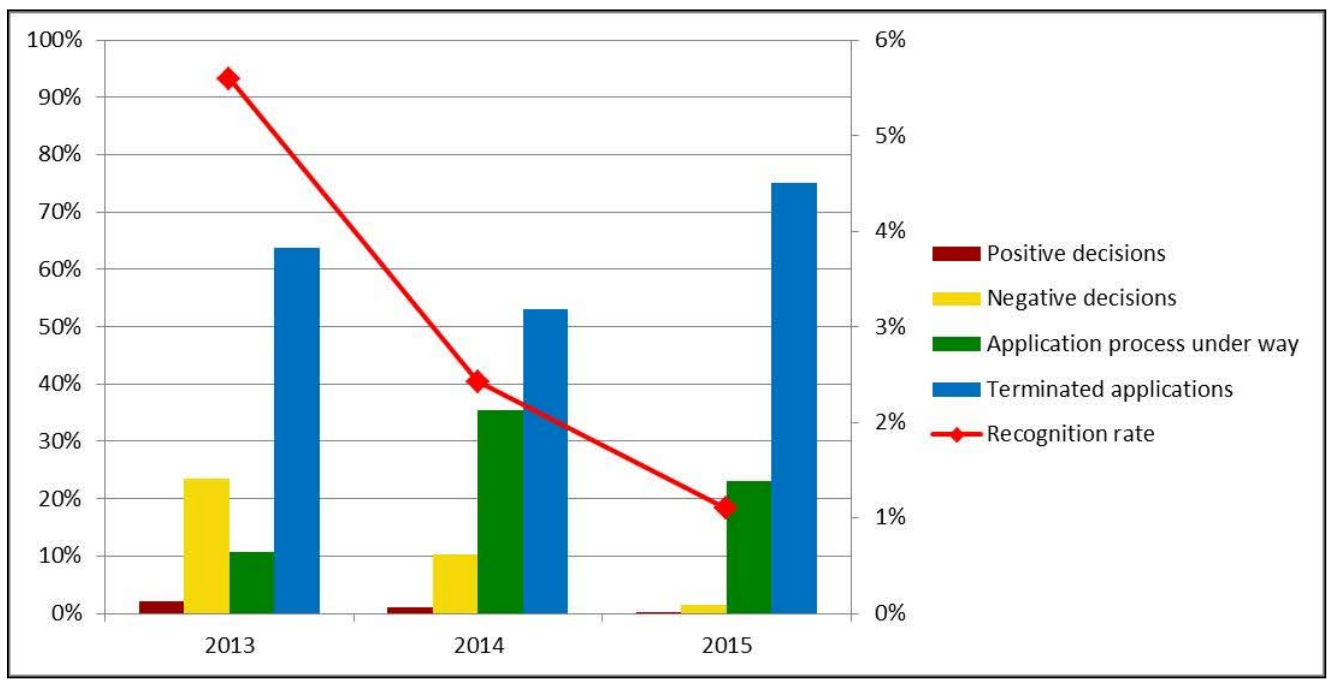

FIGURE 3 The trends of asylum applications 
expulsion. Expulsions have been facilitated by the change of law, according to which Serbia is now considered a safe third country. Those who were not prosecuted either came through another section of the border, and only committed an offence or were minors and therefore could not be penalized. The increase in migration flows is also indicated by the fivefold growth in penal proceedings related to human smuggling, rising to 1,200 cases in two years.

\section{Service providers and the lack of services}

In recent years it has become a growing problem that after the gradually shortening subsidized period refugees face serious housing problems, partly for the lack of available social/council housing and partly because landlords are less likely to lease houses or flats to foreigners. In the meantime civilians try to reach the public, either by raising awareness about discrimination or by celebrity endorsement (http://menedek.hu/hirek/velkam-majgrentsz-alberletet-keresunk). Yet, refugees and subsidiary protection beneficiaries can be often found in public shelters, homeless shelters or on the streets after they leave the camps. Reducing the maximum length of stay at reception centres to two months have paralyzed groups that are not yet able to integrate into the labour market and many of whom are traumatized too. Unaccompanied children are placed at special children's homes, however fluctuation is typically high because unaccompanied children soon flee and they are rarely sent back to Hungary in the framework of the Dublin procedure. Since the spring of 2016 services have shrunk even further: the financial support linked to the integration contract, as well as housing, schooling subsidies have been terminated, therefore a greater role has been attributed to formal and informal non-governmental organizations: they do their best to find a place for refugees leaving the camps, fight against homelessness and begging.

\section{ON THE ROAD TO NEO-INTEGRATION OR CONNECTING TO THE GLOBAL DIASPORA NETWORK}

The negative reception of refugees by agencies, service providers or the majority of the society drives refugees towards homogeneous relations: the ethnically, linguistically or religiously homogeneous connections in the refugees' ego-network are more significant than the ones to the host society. A significant part of the relations go beyond the diasporas, but remain in the sphere of diasporas because of the common religion or language (Figure 4). In the case of refugees neo-integration means the process in which the refugees who have left their former social milieu behind, integrate into the host society through a transnational network in which previous relation failures, social and societal successes are decisive, and this is a reflected, conscious, value- and interest-driven process. The hub of a diaspora becomes the centre of the diaspora and concurrently serves as a bridge towards the host society, economic actors or even towards non-governmental organizations.

However, diaspora networks do not stay inside national borders, they have many ties to the homeland through relatives living in the countries of origin or neighbouring countries, and most of them have contacts in Western Europe and other regions. Due to this feature the diasporas connect to a global diaspora network which spans enormous distances, albeit in an ethnically and religiously 


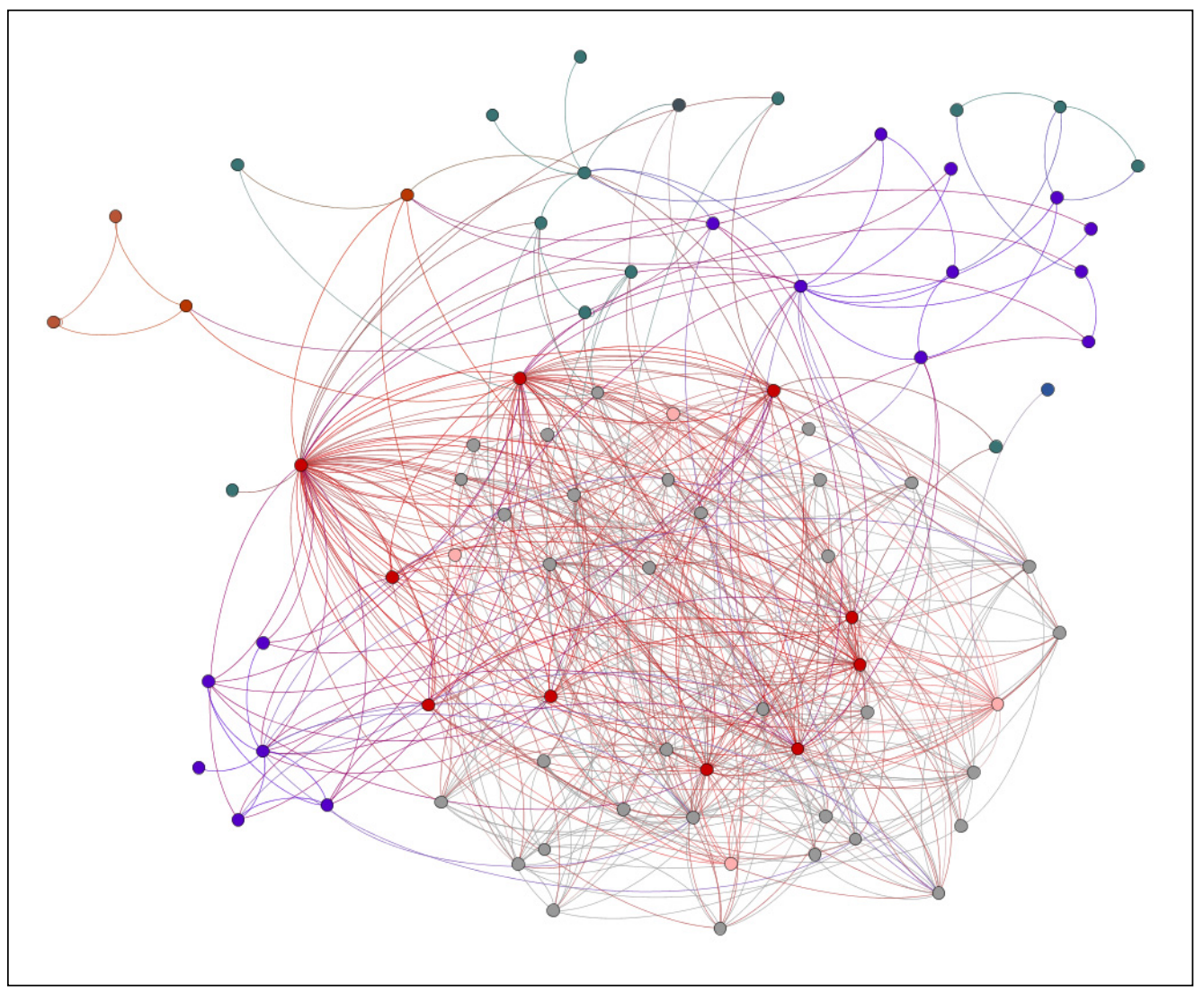

FigURE 4 An example: the Somali diaspora in Budapest and its transnational cooperative relations

differentiated way. The global diaspora network is not only a forum for keeping contact. In addition to instrumental ties it also has an economic potential which can support both resettlement and moving further. It is primarily the hubs that can benefit from this. This is crucial for the people of diasporas in Hungary, because labour market integration in Hungary can support neither subsistence, nor progress. Jobs and especially social benefits do not provide the means for supporting family members back home, so it is particularly important for migrants to become self-employed or move further west.

This sole example clearly illustrates that while we talk about encounters and the reception of refugees, the reception of refugees in Hungary is determined by transnational relations that lead refugees towards ethnically and religiously homogenous communities, and they rarely keep up supportive relations that bind them to the host society. In this field we can perceive exoticism and paradoxes of foreignness. 


\section{CONCLUSION: RECEPTION AND REJECTION}

In different segments of power and in the associated (moderate or extreme) right-wing press, the reception of refugees appears clearly with aversion, xenophobia, social, economic and cultural burden along with health risks, and more and more often in the context of terrorism. Left-wing newspapers and political blocs stood up for the refugees cautiously at first and then more and more vividly, and approached the issue from the aspect of the humanitarian crisis, while independent NGOs created a growing and increasingly fragmented helping network. On this side foreignness appears as an attractive or at least interesting exotic feature.

The government has repeatedly started an apology-like discourse by speaking about other social problems, the modest economic indicators and the liability of other countries. The latter included other Schengen states, the wealthier half of the Union, the liability of those who triggered the Arab Spring, as well as the southern states and Turkey, which would have had a role in stopping the refugee wave.

After the wave of refugees subsided in Hungary - when the Balkan route turned to Slovenia through Croatia, and the daily number of refugees in Hungary decreased to two-digit figures, the government's anti-refugee discourse took a new turn. On the one hand, they appeared as the guardians of the Schengen border, showing solidarity with other countries for the protection of the borders. On the other hand, the refugees were described as aggressive assailants of European culture and terrorists. The government rejects the reception of refugees - both by protesting against the quota system and through legal and physical border closure. The anti-refugee discourse is amplified in right-wing movements, groups and in the social media through continuing stereotypical, racist, xenophobic and hateful communication.

However, positive neutrality among civilians has been replaced by a high degree of activity. Knowledge-sharing and facilitating networks and a series of informal contacts have taken action to help during the humanitarian crisis. The inclusion of humane and professional gestures, the shocking and uplifting, but surely intense experience has created powerful ties which can constitute a strong background for NGOs dealing with refugees and can also help other initiatives launched to assist disadvantaged groups.

Overall, the negative attitude towards refugees, the change of acceptance criteria and power discourses reinforcing criminalization provoked such a strong opposition which has mobilized the civil society and has broadened the group who are open to transnational encounters in their social relations and are willing to receive refugees. However, anti-migrant sentiment has also lost some of its modesty, and the media continuously refers to refugees as a source of problems. The fear of migrants, which has become a defining element of social discourse, has reorganized the political discourses too. The anti-refugee attitude of the government can be detected not only at the level of discourses but also in the tightening of the legal framework, in decreasing inclusion and in the dismantling of the support system.

However, refugees and many migrants who arrived previously have not left the country. They and other people with migrant background must face xenophobic discourses as well as intolerance on the labour market and in everyday life. However, with the current regulations in place it is not expected that other large groups of refugees will have to face this negative reception. 
Refugees still trying to go through Hungary must either turn back or choose the illegal way. The few who do gain protection/asylum, will move on or get connected via the diasporas: primarily to the global diaspora networks and secondly to the Hungarian society. This also indicates that although we wish to speak of a local phenomenon, it is bound to other localities and authorities through multiple ties. The dynamics of inclusion and neo-integration are affected not only by changes in the situation in Hungary, but also by political attitudes, the reception policy of the EU, the reception capacity of the diasporas, personal commitments and plans as well as the influence of the authorities and the media on the local discourse.

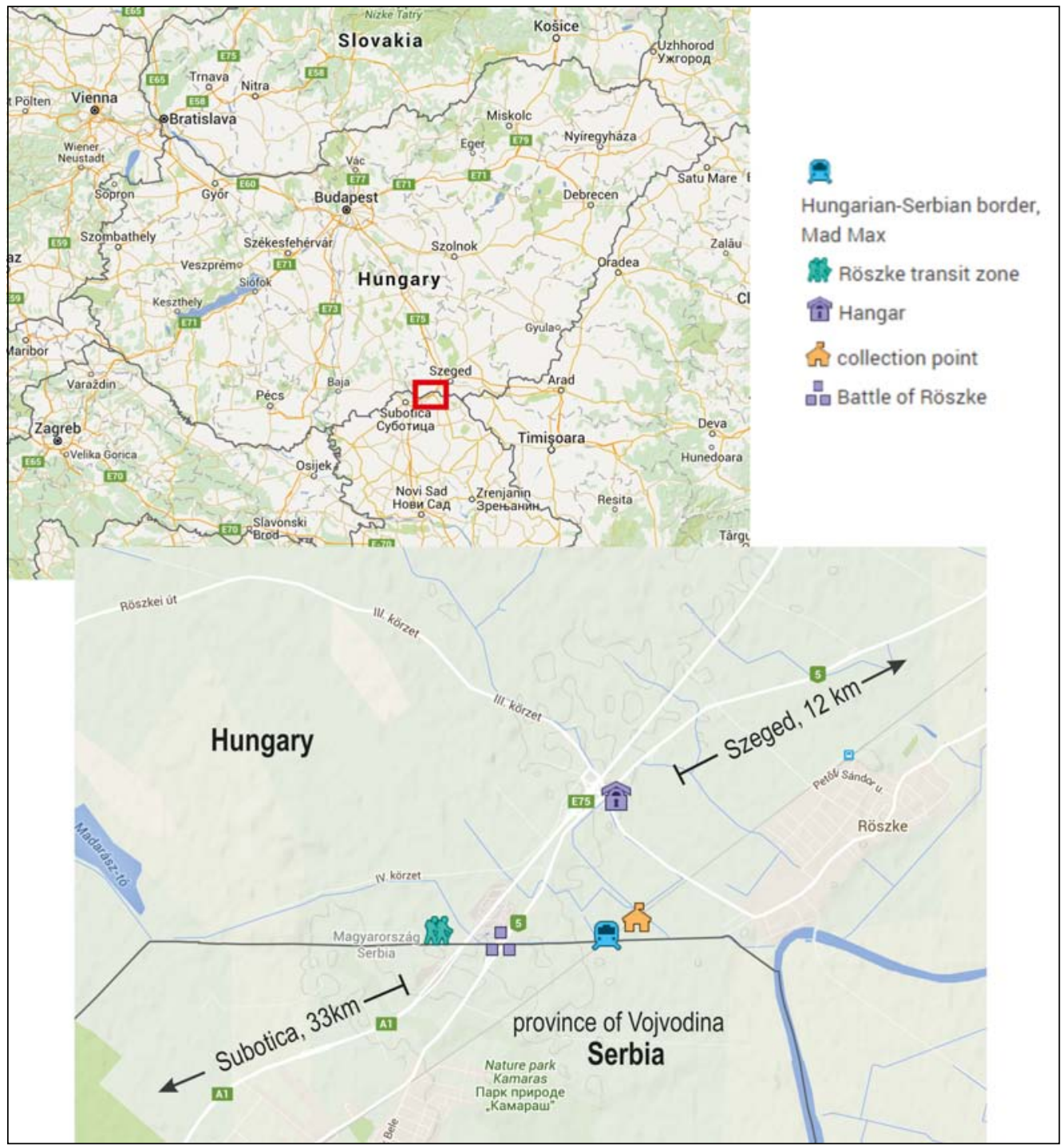

FIGURE 5 The main localities 


\section{BIBLIOGRAPHY}

A. Gergely, A. (2005): Szórvány, diaszpóra és határfenntartás. Adalékok a szórványtipológia és a kulturális sziget kérdésköréhez. In ILYÉs, Z. (ed.): Tanulmányok a szórványról. Budapest: Gondolat Kiadó - MTA Etnikai-nemzeti Kisebbségkutató Intézet. pp. 11-20. Available at www.mtaki.hu/kiadványok, http://www.publikon.com/application/essay/402_1.pdf (23/01/2016) BERnÁth, G. - Messing, V. (2015): Bedarálva. A menekültekkel kapcsolatos kormányzati kampány és a tőle független megszólalás terepei. Médiakutató 16. évf. 4. sz. 7-17.

Brubaker, R. (2005): The 'diaspora' diaspora. Ethnic and Racial Studies vol. 28. no. 1. 1-19. САВОт, Н. (2016): Contagious solidarity: reconfiguring care and citizenship in Greece's social clinics. Social Anthropology vol. 24. no. 2. 152-166.

Clifford, J. (2007): Varieties of Indigenous Experience: Diasporas, Homelands, Sovereignties. In CAdenA, M. DE LA - StARn, O. (eds.): Indigenous experience today. Oxford, Wenner-Gren Foundation for Anthropological Research - Berg Publishers. 197-224.

FÁBIÁN, Z. - SiK, E. (1996): Előítéletesség és tekintélyelvűség. In ANDORKA R., Kolosi T. VuKovich Gy. (eds.): Társadalmi riport 1996. Budapest, TÁRKI - Századvég. 381-413.

FAIST, TH. (2010) ‘Diaspora and transnationalism. What kind of dance partners?' In BAUBOCK, R. FAIst, TH. (eds.): Diaspora and Transnationalism. Concepts. Theories and Methods. Amsterdam, Amsterdam University Press. 9-34.

FoKASZ, N. (2006): A szenzáció, az örökzöld és a gumicsont. Jel-Kép no. 3-4. 71-92.

FOKASZ, N. (2008): Evergreens, sensations and the rest. A quantitative analysis of dynamics of news articles on domestic politics. Review of Sociology vol. 14. no. 1. 5-24.

GLICK SCHILLER, N. (2010): A global perspective on transnational migration. Theorising migration without methodological nationalism. In BAuBock, R. - FAIst, TH. (eds.): Diaspora and Transnationalism. Concepts, Theories and Methods. Amsterdam, Amsterdam University Press. 109-130.

HANNERZ, U. (1997): 'Fluxos, fronteiras, hibridos: palavras-chave da antropologia transnacional'. Mana (Rio de Janeiro) vol. 3. no. 1. 7-39. Available at http://www.transcomm.ox.ac.uk/ working\%20papers/hannerz.pdf (25/01/2016)

HOLMES, S. M. - CASTANEDA, H. (2016): Representing the "European refugee crisis" in Germany and beyond. Deservingness and difference, life and death. American Ethnologist vol. 43. no. 1. 12-24.

Hungarian Helsinki Committee: Itt hamarosan "jogi határzár" épül. Átfogó támadás a menedékjog intézménye ellen. 10/07/2015. Available at http://helsinki.hu/wp-content/uploads/Itt-hamarosanjogi-hatarzar-epul-_-Helsinki-Biz-menekultugy-jogszabalyvaltozas.pdf (18/01/2016)

Orbán: Örülünk a kebabosoknak, de ne jöjjenek többen! index.hu 07/09/2015 Available at http://index.hu/belfold/2015/09/07/orban_nincs_ellenunkre_a_kvota/ (12/12/2015) 
KovÁts, A. (2003): Menekültek társadalmi beilleszkedése Magyarországon a Bevándorlási és Állampolgársági Hivatal adatai alapján. In KovÁcs N. - SzARKA L. (eds.): Tér és terep. Tanulmányok az etnicitás és az identitás kérdésköréből. 2. Budapest, Akadémiai Kiadó. 181-198.

„Akik itt vannak, menjenek haza”. Magyar Nemzet Online, 08/05/2015. Available at http://mno.hu/ belfold/orban-akik-itt-vannak-menjenek-haza-1286779 (25/01/2016)

Az Európába irányuló és 2015-től felgyorsult migráció tényezői, irányai és kilátásai. A Magyar Tudományos Akadémia Migrációs Munkacsoportjának elemzése. MTA, 2015. Available at http://mta.hu/data/cikk/13/70/8/cikk_137008/_europabairanyulo.pdf (25/01/2016)

NAGY, T. (2009): Narrativ menekültsors. A hatalom és mobilitás kérdései. (Narrative fate of refugees. The questions of power and mobility.) In JANCSÁK Cs. - NAGY G. D. - SzÜCS N. (eds.): Céhem vándorkönyvei. Tanulmányok a 60 éves Pászka Imre tiszteletére. Szeged, Belvedere Meridionale. 89-103.

NAGY, T. (2010): Kötödések és kudarcok. A kapcsolatok és kapcsolati kudarcok szerepe az integrációban. Egy menekültek körében végzett terepmunka eredményei. Attachments and Failures Role of Ties and Failures of Ties in Integration Results of a Fieldwork among Refugees. $\mathrm{PhD}$ thesis. Available at http://phd.lib.uni-corvinus.hu/437/ (16/12/2015)

NAGY, T. (2011): Utazó kultúrák és a diaszpórák letelepedése. (Travelling cultural patterns and the establishment of diasporas.) Tér és Társadalom vol. 25. no. 4. 20-37.

National Consultation, 2015. 'Nemzeti konzultáció a bevándorlásról és terrorizmusról, 2015.' Available at http://www.kormany.hu/download/7/e2/50000/nemzeti_konzultacio_bevandorlas_2015.pdf $(25 / 01 / 2016)$

RAJARAM, P. K. - ARENDAS Zs. (2013): Exceeding categories: law, bureaucracy and acts of citizenship by asylum seekers in Hungary. In IsIN, E. F. - SAWARD, M. J. (eds.): Enacting European Citizenship. Cambridge University Press. 195-219.

RozAKou, K. (2016): Socialities of solidarity: revisiting the gift taboo in times of crises. Social Anthropology vol. 24. no. 2. 185-199.

SAFran, W. (1991): Diasporas in Modern Societies. Myths of Homeland and Return. Diaspora vol. 1. no. 1. 83-99.

SCHIFFAUER, W. (2004): Félelem a különbözőségtől. Új áramlatok a kultúr- és szociálantropológiában. In Biczó G. (ed.): Az Idegen. Variációk Simmeltől Derridáig. Debrecen, Csokonai Kiadó. 151-161.

SIK, E. (2012): „Nem mérlegelünk - Nem kellenek az idegenek”. Tárkitekintő. Available at http://www.tarki.hu/hu/news/2012/kitekint/20120516_idegenellenesseg.html (13/01/2016)

Szeged Studies (2016): Szeged Studies. The annual study by the Department of Sociology, University of Szeged'

TÁRKI (2015) Nem nött tovább, de magas az idegenellenesek aránya. Available at http://www.tarki.hu/ hu/news/2015/kitekint/20150804_idegen.html (13/01/2016) 
The Guardian 06/01/2016 'Is humour the best weapon against Europe's new wave of xenophobic nationalism?' Available at http://www.theguardian.com/world/2016/jan/06/hungary-two-taileddog-viktor-orban (06/01/2016)

TILly, Ch. (2001): Áthelyeződött hálózatok. In SIK, E. (ed.): A migráció szociológiája. Budapest, Szociális és Családügyi Minisztérium. 89-103.

ViCSEK, L. - KeSZI, R. - MÁrKus, M. (2008): Representation of Refugees, Asylum-Seekers and Refugee Affairs In Hungarian Dailies. Journal of Identity and Migration Studies vol. 2. no. 2. 87-107. WAHLBECK, O. (2002): The concept of diaspora as an analytical tool in the study of refugee communities. Journal of Ethnic and Migration Studies vol. 28. issue 2. 221-238.

WILSON, T. F. (2009): The conservative aspects of a centripetal diaspora: The case of the Cape Verdean tabancas Africa. The Journal of the International African Institute vol. 79. issue 4. 520-542.

\title{
The sources of the examined text corpuses
}

\author{
hvg.hu/itthon \\ index. $h u$ \\ delmagyar.hu \\ nol.hu \\ mno.hu \\ alfahir.hu
}

